Brit. J. industr. Med., 1962, 19, 283.

\title{
A STUDY OF ACRYLONITRILE POISONING IN RELATION TO METHAEMOGLOBIN-CN COMPLEX FORMATION
}

\author{
BY \\ LADISLAUS MAGOS \\ From the State Institute of Occupational Medicine, Department of Industrial Hygiene, \\ Budapest, Hungary
}

(RECEIVED FOR PUBLICATION FEBRUARY 12, 1962)

\begin{abstract}
Observations are recorded on methaemoglobin- $\mathrm{CN}$ complex formation in rats poisoned with acrylonitrile, potassium cyanide, and acetone cyanohydrin. For information on methaemoglobin$\mathrm{CN}$ formation, the methaemoglobin level was increased by sodium nitrite.

The results show that the rate of methaemoglobin- $\mathrm{CN}$ formation in rats killed by acrylonitrile is lower than in animals surviving potassium cyanide or acetone cyanohydrin poisoning, and much lower than in animals killed by potassium cyanide. These findings indicate that the toxicity of acrylonitrile cannot be solely due to the liberation of cyanide.
\end{abstract}

There is a divergence of opinion about the toxic action of acrylonitrile; that the action of acrylonitrile was due to cyanide was accepted by Dudley and his collaborators (Dudley and Neal, 1942; Dudley, Sweeney, and Miller, 1942) on the basis of symptoms, and by Brieger, Rieders, and Hodes (1952), who detected blood cyanide, cyanmethaemoglobin, and thiocyanate excretion. The determination of the rate of cyanmethaemoglobin formation in the range of normal methaemoglobin levels seems, however, to be somewhat problematical.

On the other hand, Ghiringhelli (1956) and Beneš and Černá (1959) found that only 20 to $25 \%$ of the cyanide ions were excreted as thiocyanate in acrylonitrile poisoning, and because of this, the latter supposed that acrylonitrile killed by the action of the intact molecule rather than by the detached cyanide ions.

Nevertheless, the relatively low thiocyanate excretion does not disprove the cyanide effect. In Ghiringhelli's (1956) experiment, the guinea-pigs treated with an $L^{2} D_{50}$ of acrylonitrile excreted over five and a half times more thiocyanate than the animals treated with an $\mathbf{L D}_{50}$ of sodium cyanide. Consequently, although the incomplete liberation of cyanide has been demonstrated, the liberation of cyanide in lethal amounts has not been shown to be impossible.

The toxic action of cyanide is characterized by its ability to form complexes with metalloproteins. Therefore, this study has been based on the assump- tion that the question of the liberation of cyanide in lethal amounts can be answered by determining the rate of metalloprotein-CN complex formation. Although the most important metalloprotein in this relation is the cytochromoxidase, nevertheless the methaemoglobin offers the easiest way to approach the problem.

It is well known that the formation of both cytochromoxidase-CN and methaemoglobin-CN complexes depends on the cyanide concentration. From the following equation,

$$
\frac{\mathrm{K}_{\mathrm{M}}}{\mathrm{K}_{\mathrm{o}}} \times \frac{\text { Meth-CN } \%}{\text { Meth } \%}=\frac{\text { oxidase-CN } \%}{\text { oxidase } \%},
$$

if meth- $\mathrm{CN} \%$ and meth $\%$ are determined, it is possible to calculate the approximate degree of cytochromoxidase inhibition. The cause of uncertainty in this calculation is that $K_{M}$ and $K_{o}$ (the dissociation constants of meth- $\mathrm{CN}$ and oxidase-CN) are only estimated in in vitro experiments. The dissociation constant of meth-CN is $6 \times 10^{-6}$ (Scheler, Schoffa, and Jung, 1958), and the dissociation constant of oxidase- $\mathrm{CN}$ in pre-incubation with cyanide is $3 \times 10^{-6}$ (Wainio and Greenlees, 1960).

To obtain information on metalloprotein- $\mathrm{CN}$ complex formation it was necessary to increase the methaemoglobin level by sodium nitrite treatment. Thus, the study also involved a test of the protective effect of methaemoglobin formation. For purposes of comparison, data on the methaemoglobin- $\mathrm{CN}$ 
formation caused by potassium cyanide and acetone cyanohydrin are also presented.

\section{Experimental Procedures and Methods}

Male albino rats weighing between 160 to $180 \mathrm{~g}$. were used.

The materials were the following: $10 \times 10^{-1} \mathrm{M}$ aqueous acrylonitrile; $5 \times 10^{-2} \mathrm{M}$ aqueous potassium cyanide; $5 \times 10^{-2} \mathrm{M}$ aqueous acetone cyanohydrin; and $1 \%$ aqueous sodium nitrite.

Procedures.- $a$. Before the experiment it was necessary to determine the $\mathrm{LD}_{50}$ of the cyanide compounds in question. The substances were injected subcutaneously, the dosage series calculated in millimole alternated in accordance with the scheme of Deichmann and LeBlanc (1943), i.e. the larger exceeded the smaller by $50 \%$.

$b$. Subsequently, 10 animals were treated with a dose $1.5 \times \mathrm{LD}_{50}$. Five animals from each group were given $30 \mathrm{mg}$. sodium nitrite per $\mathrm{kg}$. of body weight intraperitoneally 30 minutes before the treatment with the cyanide compounds. An additional four animals treated with sodium nitrite were given potassium cyanide in a dose $2.25 \times \mathbf{L D}_{50}$.

c. Blood samples for methaemoglobin- $\mathrm{CN}$ estimation were taken from the heart immediately after death or from the tail vein one hour after the injection of the cyanide compounds.

d. Methaemoglobin and Methaemoglobin-CN Determination.-To $10 \mathrm{ml}$. of phosphate buffer, $p \mathrm{H} 6 \cdot 6,0 \cdot 1$ $\mathrm{ml}$. blood was transferred, and haemolysed with a trace of saponin. To remove turbidity, the solution was centrifuged at $1,900 \mathrm{G}$ for 20 minutes.

The optical density was read at $630 \mathrm{~m} \mu$ in a Beckman spectrophotometer model DU, with tungsten lamp and $10 \mathrm{~mm}$. glass cuvettes (slit $0.035 \mathrm{~mm}$.) before $\left(E_{1}\right)$ and after $\left(E_{2}\right)$ adding a drop of $23 \%$ potassium ferricyanide to the solution. The increase of optical density is inversely proportional to the total methaemoglobin concentration. After this, one drop of $10 \%$ acetone cyanohydrin was added to the sample to convert the methaemoglobin to methaemoglobin- $\mathrm{CN}$, and the optical density was read again at $630 \mathrm{~m} \mu\left(\mathrm{E}_{3}\right)$. The decrease of density is inversely proportional to the original methaemoglobin- $\mathrm{CN}$ concentration. After the potassium ferricyanide and acetone cyanohydrin treatment, the samples were allowed to stand three minutes for complete conversion.

The total haemoglobin was determined as methaemoglobin-CN at $540 \mathrm{~m} \mu$ (slit: 0.02) after the sample was diluted with buffer to a double volume and treated with a drop of concentrated ammonium hydroxide $\left(E_{4}\right)$.

The calculation was as follows.

Total haemoglobin $\mathrm{g} . \%=\mathrm{E}_{4} \times 30.34$.

Total methaemoglobin g. $\%=\left(E_{4} \times 30 \cdot 34\right)-\left(E_{2}-E_{1}\right)$ $\times 45 \cdot 8$.

Methaemoglobin-CN g. $\%=\left(E_{4} \times 30 \cdot 34\right)-\left(E_{2}-E_{3}\right)$ $\times 50 \cdot 7$.

Methaemoglobin g. $\%=($ total methaemoglobin g. $\%)$ -(methaemoglobin-CN g. $\%$ ).

The maximal error is $0.30 \mathrm{~g} . \%$ methaemoglobin-CN. The rate of methaemoglobin- $\mathrm{CN}$ formation is expressed in percentages as a ratio of methaemoglobin- $\mathrm{CN}$ to total methaemoglobin.

The factor for calculating total haemoglobin was based on the extinction coefficient given by Zijlstra and Kampen (1960).

\section{Results}

Median lethal doses (Table 1) were exceeded at a similar rate in the investigation of both the preventive effect of sodium nitrite and the methaemoglobin$\mathrm{CN}$ formation.

TABLE 1

APPROXIMATE MEDIAN LETHAL DOSES OF ACRYLONITRILE, POTASSIUM CYANIDE, AND ACETONE CYANOHYDRIN ADMINISTERED SUBCUTANEOUSLY TO ALBINO RATS

\begin{tabular}{l|c|c}
\hline \multicolumn{1}{c|}{ Compound } & Millimole/kg. & $\mathrm{mg} . / \mathrm{kg}$. \\
\hline Acrylonitrile & 1.8 & $95 \cdot 8$ \\
Potassium cyanide & $1.6 \times 10^{-1}$ & 10.4 \\
Acetone cyanohydrin & $1.0 \times 10^{-1}$ & 8.5 \\
\hline
\end{tabular}

Table 2 shows the proportion of animals dying to the number that were given one of the three cyanide compounds with or without sodium nitrite treatment.

TABLE 2

EFFECT OF METHAEMOGLOBINAEMIA ON MORTALITY RATIOS IN ALBINO RATS POISONED WITH ACRYLONITRILE, POTASSIUM CYANIDE, AND ACETONE CYANOHYDRIN

\begin{tabular}{|c|c|c|c|}
\hline \multirow{2}{*}{ Compound } & \multirow{2}{*}{$\underset{\text { (millimole/kg.) }}{\text { Dose }}$} & \multicolumn{2}{|c|}{$\begin{array}{l}\text { No. That Died/No. } \\
\text { Given Cyanide Compound }\end{array}$} \\
\hline & & $\begin{array}{l}\text { Without } \\
\text { Sodium } \\
\text { Nitrite }\end{array}$ & $\begin{array}{l}\text { With } \\
\text { Sodium } \\
\text { Nitrite }\end{array}$ \\
\hline $\begin{array}{l}\text { Acrylonitrile } \\
\text { Potassium cyanide } \\
\text { Potassium cyanide } \\
\text { Acetone cyanohydrin }\end{array}$ & $\begin{array}{l}2.8 \\
2.4 \times 10^{-1} \\
3.7 \times 10^{-1} \\
1.6 \times 10^{-1}\end{array}$ & $\begin{array}{l}5 / 5 \\
5 / 5 \\
5 / 5\end{array}$ & $\begin{array}{l}5 / 5 \\
1 / 5 \\
4 / 4 \\
0 / 5\end{array}$ \\
\hline
\end{tabular}

On this experimental condition the sodium nitrite which was effective in the case of both potassium cyanide and acetone cyanohydrin, changed neither the mortality ratio nor the period between the injection of acrylonitrile and death. The survivals in minutes are given in Table 3.

TABLE 3 SURVIVAL IN MINUTES

\begin{tabular}{|c|c|}
\hline With Sodium Nitrite & Without Sodium Nitrite \\
\hline $\begin{array}{r}93 \\
111 \\
116 \\
130 \\
141\end{array}$ & $\begin{array}{l}104 \\
115 \\
118 \\
121 \\
122\end{array}$ \\
\hline Average 118 & 116 \\
\hline
\end{tabular}


TABLE 4

COMPARISON OF METALLOPROTEIN-CN COMPLEX-FORMING CAPACITY OF CYANIDE COMPOUNDS AFTER SODIUM NITRITE ADMINISTRATION

\begin{tabular}{|c|c|c|c|c|c|}
\hline \multirow{2}{*}{ Compound } & \multirow{2}{*}{ No. of Rats } & \multirow{2}{*}{$\begin{array}{l}\text { Time of Taking } \\
\text { Blood Samples }\end{array}$} & \multicolumn{2}{|c|}{ Ratio of Meth-CN to Total Meth } & \multirow{2}{*}{$\begin{array}{c}\text { Approximate Inhibition } \\
\text { of Cytochromoxidase } \\
(\%)\end{array}$} \\
\hline & & & Mean & S.D. & \\
\hline $\begin{array}{l}\text { Acrylonitrile } \\
\text { Potassium cyanide }\end{array}$ & $\begin{array}{l}5 \\
5\end{array}$ & $\begin{array}{l}\text { After death } \\
\text { After death }\end{array}$ & $\begin{array}{l}55 \cdot 8 \\
85 \cdot 6\end{array}$ & $\begin{array}{r}14 \cdot 8 \\
8 \cdot 7\end{array}$ & $\begin{array}{l}71 \cdot 5 \\
92 \cdot 2\end{array}$ \\
\hline $\begin{array}{l}\text { Potassium cyanide } \\
\text { Acetone cyanohydrin }\end{array}$ & $\begin{array}{l}4 \\
5\end{array}$ & $\left\{\begin{array}{l}\text { One hour after } \\
\text { cyanide administra- } \\
\text { tion }\end{array}\right.$ & $72 \cdot 4$ & $12 \cdot 7$ & $84 \cdot 0$ \\
\hline
\end{tabular}

Blood samples taken from rats killed by acrylonitrile or potassium cyanide revealed a significant difference $(t=4.06,0.01>p>0.001)$ in the rate of methaemoglobin- $\mathrm{CN}$ formation expressed in percentage as a ratio of methaemoglobin-CN to total methaemoglobin. Blood samples from surviving animals taken one hour after the injection of potassium cyanide or acetone cyanohydrin also showed a higher rate of methaemoglobin$\mathrm{CN}$ formation than those of animals killed by acrylonitrile.

Table 4 shows in addition to the methaemoglobin$\mathrm{CN}$ values, the approximate inhibition of cytochromoxidase calculated from the ratio of methaemoglobin-CN: methaemoglobin and based on the assumption that $\mathrm{K}_{\mathrm{M}}: \mathrm{K}_{\mathrm{O}}=2$.

\section{Discussion}

One of the most important features of the mechanism of intoxication by cyanide ions is the metalloprotein-CN complex formation. There have been no studies on record in which this fundamental phenomenon has been analysed in poisoning with acrylonitrile. Approaching the problem from this point of view, this work has revealed clear differences between acrylonitrile and potassium cyanide or acetone cyanohydrin.

In contrast to low thiocyanate excretion found by Ghiringhelli (1956) and Beneš and Černá (1959), more than half of the methaemoglobin binds cyanide ions in animals killed by acrylonitrile. Notwithstanding, this diversion of $\mathrm{CN}$ does not seem to play a prominent role in the lethal effect of acrylonitrile.

This hypothesis is supported by two facts.

$a$. Although the rate of methaemoglobin-CN formation is high, it is lower than in animals surviving potassium cyanide or acetone cyanohydrin poisoning, and much lower than in animals killed by potassium cyanide.

$b$. The considerable quantity of cyanide trapped by methaemoglobin had no effect either on the mortality or the time of survival.

However, the hypothesis may not be generally applicable. Dudley and Neal (1942), Dudley et al. (1942) and Brieger et al. (1952) showed that there was a discernible difference between species in their susceptibility to acrylonitrile. In the experiments of Brieger and co-workers (1952) the cyanide concentration in the blood of dogs was always higher than in rats, whereas the reverse applied to the urine thiocyanate. In spite of rapid cyanide detoxication in rats, a very remarkable quantity of metalloprotein- $\mathrm{CN}$ complex formation was detected in the present study. In species with slower conversion of cyanide to thiocyanate, therefore, the possibility of lethal cyanide liberation cannot be excluded.

Nevertheless, the facts mentioned above show that the toxicity of acrylonitrile is not due to the metabolic formation of cyanide ions in every case, and the hypothesis of Beneš and Černá (1959), which is accepted by Paulet and Desnos (1961), seems to be justified. Thus, the toxicity of acrylonitrile cannot be due solely to cyanide liberation as Williams (1959) has implied.

It is well known that acrylonitrile is an exceptionally reactive compound, and it is entirely reasonable to assume that important constituents of biochemical mechanisms can be damaged, e.g. by cyanoethylation. There are very many compounds having the structure $\mathrm{HX}$, where $\mathrm{H}$ is a reactive hydrogen atom which adds readily to the carbon-carbon double bond of acrylonitrile (American Cyanamid Company, 1951).

There is a possibility that after acrylonitrile administration the cyanide formed in statu nascendi in the tissues might act at a lower concentration than after administering potassium cyanide. In this case, on the basis of both the difference in methaemoglobin-CN complex formation caused by potassium cyanide and acrylonitrile and the negative effect of sodium nitrite treatment, we must suppose that the cyanide formation after acrylonitrile administration is a result of a reaction including cytochromoxidase and acrylonitrile. If this hypothesis is true, the importance of the direct effect of acrylonitrile should be again stressed. 


\section{REFERENCES}

American Cyanamid Company (1951). The Chemistry of Acrylonitrile. (Cyanamid's Nitrogen Chemicals Digest, Vol. 5). New York. Benes, V., and Cerná, V. (1959). J. Hyg. Epidem. (Praha), 3, 106. Brieger, H., Rieders F., and Hodes, W. A. (1952). A.M.A. Arch.

Deichmann, W. B., and LeBlanc, T. J. (1943). J. industr. Hyg., 25. 415.

Dudley, H. C., and Neal, P. A. (1942). ibid., 24, 27.
Sweeney, T. R., and Miller, J. W. (1942), ibid., 24, 255.

Ghiringhelli, L. (1956). Med. d. Lavoro, 47, 192

Paulet, G. and Desnos, J. (1961). Arch, int Pharmacodyn., 131, 54. Scheler, W., Schoffa, G., and Jung, F. (1958). Acta biol. med. germ. 1, 32.

Wainio, W. W., and Greenlees, J. (1960). Arch. Biochem., 90, 18.

Williams, R. T.'(1959). Detoxication Mechanisms, 2nd ed. Chapman and Hail, London.

Zijlstra, W. G., and Kampen, E. J. van (1960). Clin. chim. Acta, 5, 